\title{
Using non-conspicuous metrics to examine selected impacts of disturbance on a long-lived reptile
}

\author{
Charles R. Knapp ${ }^{1,3, *}$, Caro Perez-Heydrich ${ }^{2}$ \\ ${ }^{1}$ San Diego Zoo Institute for Conservation Research, 15600 San Pasqual Valley Road, Escondido, California 92027, USA \\ ${ }^{2}$ Carolina Population Center, University of North Carolina at Chapel Hill, CB 8120, University Square, \\ 123 West Franklin Street, Chapel Hill, North Carolina 27516, USA \\ ${ }^{3}$ Present address: Daniel P. Haerther Center for Conservation and Research, John G. Shedd Aquarium, \\ 1200 South Lake Shore Drive, Chicago, Illinois 60605, USA
}

\begin{abstract}
Loss or disturbance of habitat often results in landscapes being fragmented into a series of isolated remnants varying in size, quality, and conservation value. Habitat disturbance has deleterious consequences for ecosystem processes, but can have varying effects on species persistence. Many deleterious effects on species post-disturbance are obvious, yet some are more subtle and can elude detection in long-lived species. We used more subtle metrics to evaluate populations of endangered iguanas Iguana delicatissima inhabiting disturbed (i.e. low- to moderate-density villages and towns) and non-disturbed areas on the island of Dominica, West Indies. We investigated differences in iguana sex ratios, asymptotic size, characteristic growth rate, body condition, abundance, and densities between our defined disturbed and non-disturbed habitats. Contrary to expectations, there were no statistical effects of disturbed areas on density, sex ratio, body condition, or characteristic growth rates, yet there was a slight positive effect on asymptotic body size for iguanas on Dominica. Despite these results, I. delicatissima is still affected adversely by manifold threats, as evidenced by the continued precipitous declines and local extirpations of the species across its range. Our results do, however, suggest that if factors such as degraded nest sites and killing by non-native mammalian predators are mitigated, then moderately disturbed, human-occupied areas can be managed as corridors or buffer zones for I. delicatissima in an increasingly fragmented landscape.
\end{abstract}

KEY WORDS: Caribbean $\cdot$ Conservation $\cdot$ Dominica $\cdot$ Buffer $\cdot$ Fragmentation $\cdot$ Body size $\cdot$ Iguana delicatissima

\section{INTRODUCTION}

Increases in human populations generally result in loss or degradation of habitat because of the swell of urbanization, agricultural activity, and extraction of natural resources. The resulting landscape, often fragmented into a series of isolated remnants, varies in size, quality, and conservation value (e.g. Debinski \& Holt 2000, Fahrig 2003). Such habitat loss or disturbance often has deleterious consequences for ecosystem processes, but can have varying effects on species persistence (Bender et al. 1998, Bolger et al. 2000, 2008 Estrada et al. 2002, Fagan et al. 2005, Suhonen et al. 2010). The negative effects of these activities are typically intensified on islands, which have experienced a disproportionate rate of species extirpations (Milberg \& Tyrberg 1993, Pregill \& Steadman 2009). Indeed, insular reptiles in particular have been, and continue to be, affected dramatically by the negative effects of anthropogenic processes (Honegger 1981, Case et al. 1992, Wang et al. 2009). 
Though extirpation subsequent to disturbance often needs no explanation because the causes are conspicuous (e.g. predation, hunting, loss of habitat, breeding, and/or nesting sites), disturbance can also imperil species in subtle ways (Pike et al. 2010). Consequently, populations of long-lived species that survive marginally in disturbed habitats may actually be in a gradual state of extirpation. This circumstance may elude detection by wildlife managers until it is too late to launch mitigation strategies. Therefore, identifying non-conspicuous metrics that can be used to evaluate disturbed populations is useful for conservation management, and for predicting the fate of other conspecific or even congeneric populations experiencing intensifying anthropogenic pressure.

Useful metrics for evaluating populations of reptile species include growth rates, asymptotic body size, and body condition. Growth is a key life history parameter (Andrews 1982, Clobert et al. 1998) and determines, among other important attributes, the length and age reached at sexual maturity, and maximum body size (Andrews 1976, Van Devender 1982, Webb et al. 2002). Body size, in turn, influences crucial reproductive characteristics such as clutch size and reproductive effort (Knapp et al. 2006, Kiefer et al. 2008), as well as competitive success for space, food, and mates (Jenssen et al. 2005, Fitze \& Le Galliard 2008, Pafilis et al. 2009). Body condition, an indirect measure of fat reserves, is crucial for energetically challenging activities such as migration, reproduction, and survival during periods of scarcity (Stevenson \& Woods 2006). Thus, comparative studies of growth, body size, and body condition between disturbed and non-disturbed areas may provide predictive information about habitat quality and the longterm prognosis of populations inhabiting disturbed areas.

Reptile species on most Caribbean islands have suffered extensively from the effects of habitat loss and fragmentation (Wilson et al. 2006). One species, the arboreal Lesser Antillean iguana Iguana delicatissima, was historically common in the northern Lesser Antilles. However, its range has been reduced dramatically because of habitat loss, non-native predators and competitors, hunting, road mortality, and genetic introgression with Iguana iguana. Consequently, I. delicatissima is listed as Endangered by the International Union for the Conservation of Nature (IUCN) (Breuil et al. 2010).

One island in the Lesser Antilles inhabited by this species-Dominica-is in a relatively intact state because of its small human population and consequent reduced rate of habitat loss and urbanization.
The island is characterized by a mosaic of disturbed and non-disturbed coastal features ideal for the study of the conspicuous and non-conspicuous effects of disturbance. Because Iguana delicatissima on Dominica is under intensifying pressure from recent coastal developments and road improvement projects, identifying easily obtainable metrics for assessing population health will benefit future conservation for this species on Dominica, and on other Lesser Antillean islands experiencing habitat disturbance.

The primary objective of this study was to determine whether non-conspicuous demographic parameters can be used as metrics for evaluating populations of Iguana delicatissima inhabiting disturbed (i.e. low- to moderate-density villages and towns) versus natural areas. We chose demographic parameters demonstrated to be useful for evaluating reptile populations as well as easy to obtain in the field. We investigated differences in sex ratio, asymptotic size, characteristic growth rate, and body condition between disturbed and non-disturbed areas. We hypothesized that sex ratios in disturbed areas would favor males because females are presumably more susceptible to predation by non-native mammals (e.g. dogs) when migrating to nesting sites. We also hypothesized that asymptotic size, growth rate, and body condition would be lower in disturbed areas because of reduced feeding opportunities and a reallocation of energy from growth to response to stressors (e.g. flight from immediate disturbance, interrupted feeding, etc.). Finally, we hypothesized that population abundance and density of I. delicatissima inhabiting disturbed areas would be reduced in comparison to natural areas because of an increase in non-native predators and human hunting pressure in disturbed areas.

\section{MATERIALS AND METHODS}

\section{Study species}

Iguana delicatissima is a large, long-lived species (up to $25 \mathrm{yr}$ ) with a maximum recorded snout-vent length (SVL) of $434 \mathrm{~mm}$ (Breuil et al. 2010). The species once occupied most islands from Anguilla to Martinique. However, based on historical range data, the total population of $I$. delicatissima has most likely declined $\geq 70 \%$ since European contact in the 16th century, and the existing population is severely fragmented. Moreover, only 3 populations are considered stable, and others have been extirpated within the last decade. The species can now be found only on 
the islands of Anguilla, St. Barthélemy (including the islands of Île Fourchue), St. Eustatius, Guadeloupe (including only the islands of Basse-Terre, Îles de Petite Terre and La Désirade), Dominica, and Martinique (including Îlet Chancel and Ramier; Breuil et al. 2010). I. delicatissima is a herbivore generalist, and is primarily arboreal except on extreme xeric islands with limited tree diversity. On larger volcanic islands, females migrate annually from island interiors to nest communally along coastal slopes.

\section{Study area}

Dominica is one of the largest of the eastern Caribbean islands (48 km long and $24 \mathrm{~km}$ wide), with a maximum altitude of $1447 \mathrm{~m}$. This study was conducted on the Caribbean (leeward) coast, which is characterized primarily by xeric woodland and relatively low rainfall $(<2000 \mathrm{~mm}$ ) with a pronounced dry season from February to May. The vegetation is primarily deciduous, with leaves falling during the dry season (Malhotra et al. 2007).

Our disturbed habitat areas included 5 coastal villages and towns (Coulibistri, Layou, Mero, Portsmouth and St. Joseph) ranging in population from 281 to 2977 people (Dominica Central Statistics Office 2001) (Table 1). Iguanas were captured in trees mostly along stream beds in the center of each village or town, but also in garden trees. Evidence of disturbance included reduced intact forest habitat, obvious signs of non-native mammalian predators (e.g. dogs and cats), and occasional human hunting pressure. Our non-disturbed areas included the coastal slopes of Batali Beach (15² $\left.7^{\prime} 01.15^{\prime \prime} \mathrm{N}, 61^{\circ} 26^{\prime} 49.92^{\prime \prime} \mathrm{W}\right)$ and

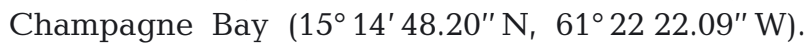

These areas were at least $1 \mathrm{~km}$ away from any coastal village and had more extensive, unfragmented forest habitat, with presumably fewer non-native mammalian predators, less road traffic, and reduced human hunting pressure (C. R. Knapp pers. obs.).

\section{Field methods}

We conducted research during 2 field seasons (April through June and August through September) each year from 2007 to 2009, and from April through June 2010. Our April through June field seasons coincided with the majority of female migrations to nest sites and oviposition activity, whereas the August through September field seasons coincided primarily with hatchling emergence. Iguanas were captured by noose, and a series of morphological measurements were recorded to the nearest $\mathrm{mm}$, including SVL, tail length (TL) and body mass (BM). Sex was determined by cloacal probing for hemipenes. For long-term identification, iguanas were affixed through their dorsal crest with a unique combination of $4 \mathrm{~mm}$ colored glass beads, and injected with passive integrated transponder (PIT) tags beneath the epidermis on the right dorsolateral side directly anterior to the pelvis.

\section{Growth model and statistical analyses}

Observed growth rates $(G)$ for each individual iguana were calculated using measurements from each subsequent capture period, and were of the form:

$$
G_{i j}=\frac{L_{i j}-L_{(i-1) j}}{D}
$$

Table 1. Human population size, cumulative vegetated area searched, abundance, density, and sex ratio of iguana (Iguana delicatissima) populations inhabiting non-disturbed sites and disturbed sites on the Caribbean coast of Dominica. Human population numbers are derived from the Dominica Population and Housing Census Report (Dominica Central Statistics Office 2001). Abundance and density results are presented with $95 \%$ confidence intervals in parentheses only for the non-disturbed sites and 3 disturbed sites with sufficient recapture histories. F: female; M: male

\begin{tabular}{|lccccc|}
\hline Site & $\begin{array}{c}\text { Human } \\
\text { population }\end{array}$ & $\begin{array}{c}\text { Vegetated } \\
\text { area (ha) }\end{array}$ & $\begin{array}{c}\text { Abundance } \\
\text { (no. of iguanas) }\end{array}$ & $\begin{array}{c}\text { Density } \\
\text { (iguanas ha }^{-1} \text { ) }\end{array}$ & $\begin{array}{c}\text { Sex ratio } \\
(\mathrm{M}: \mathrm{F})\end{array}$ \\
\hline $\begin{array}{l}\text { Non-disturbed } \\
\text { Batali Beach }\end{array}$ & - & & & & \\
Champagne Bay & - & 1.2 & $28(46-52)$ & $41(38-43)$ & $0.62: 1$ \\
$\begin{array}{l}\text { Disturbed } \\
\text { St. Joseph }\end{array}$ & 2029 & 0.75 & $12(12-13)$ & $43(42-43)$ & $0.90: 1$ \\
Layou & 467 & 0.28 & $11(8-13)$ & $36.8(28-46)$ & $1.6: 1$ \\
Coulibistri & 465 & 0.29 & $11(8-14)$ & $36(26-43)$ & $0.5: 1$ \\
Mero & 281 & 0.31 & - & - & $1: 1$ \\
Portsmouth & 2977 & 0.19 & - & - & $0.43: 1$ \\
\hline
\end{tabular}


where $j$ corresponds to an individual iguana, $i$ denotes the capture period, $L$ represents SVL, and $D$ is the number of days between capture periods $i$ and i-1. Because our data consisted of size data through time and lacked an age component, we derived a growth curve using a logistic-by-length model (Schoener \& Schoener 1978). We fitted parameters associated with this model through a Bayesian framework. We assumed $L_{i j} \sim N(\mu, \sigma)$, and defined $\mu$ according to the logistic-by-length model:

$$
\mu=\frac{a L_{(i-1) j}}{L_{(i-1) j}+a L_{(i-1) j} \mathrm{e}^{-r D}}
$$

where a (a measure of maximum length achieved) represents asymptotic length and $r$ represents the characteristic growth rate. We used an informative prior for $a$, assuming $a \sim N(386, \sigma)$, based on observed maximum lengths of iguanas in the field. We used non-informative uniform and normal priors for $\sigma$ and $r$, respectively. The WinBUGS code for this model is included in Appendix 1. We report $95 \%$ credible intervals about parameter estimates ( $a$ and $r$ ) obtained from the posterior distributions of 10000 simulations after a burn-in period of 5000 iterations.

To address differences in $a$ and $r$ between disturbed and non-disturbed areas, we fitted separate models to site-specific growth data, and compared $95 \%$ credible intervals (95\% CI) of parameter estimates to define differences in growth patterns between areas. We ran this analysis using resident animals only ( $\mathrm{n}=91)$. We defined resident and nonresident individuals based on our nesting and migration data. Nesting females migrate extensively from the island interior to coastal nesting slopes, followed by a return, from April through June, with little activity from August through September. Therefore, to isolate the potential effects of coastal disturbance and control for the effects of reproductive status or potential differences in interior habitat quality, we focused this investigation on animals that were considered permanent residents in their representative areas (captured in August or September).

We examined the effects of area disturbance on body condition (calculated for initial capture as $\mathrm{BM} / \mathrm{SVL}^{3}$ ) by evaluating between-area mean differences through a Student's t-test. We also evaluated differences in sex ratio between disturbed and nondisturbed areas using a chi-square test. Statistical significance was evaluated using an $\alpha$-level of 0.05 . The above analyses were run using the program $\mathrm{R}$ (http://www.r-project.org) and WinBUGS (Lunn et al. 2000), which we accessed through the R2WinBUGS package in R (Sturtz et al. 2005). Abundance for each non-disturbed area, and for 2 disturbed areas with robust capture histories, was estimated using the POPAN formulation in program MARK (White \& Burnham 1999). Population densities were then estimated from areas calculated using satellite imagery and verified with on-the-ground GPS coordinates.

\section{RESULTS}

Of the 91 iguanas $\left(\mathrm{n}_{\text {disturbed }}=20, \mathrm{n}_{\text {non-disturbed }}=71\right)$ captured repeatedly for this study, 48 (53\%) were captured more than twice. Growth curves resulting from mean parameter estimates suggest a slight positive effect of habitat disturbance on overall growth patterns of iguanas (Fig. 1). In general, there was no evidence to suggest a significant difference in $r$ between iguanas at disturbed versus non-disturbed sites. 95\% CI for $r$ overlapped for disturbed and nondisturbed sites $\left(r_{\text {disturbed }}=0.00131,95 \%\right.$ CI $=$ $0.00088-0.00173 ; r_{\text {non-disturbed }}=0.00172,95 \% \mathrm{CI}=$ 0.00145-0.0020; Fig. 2). Note that $r$ represents an overall daily growth rate over the projected lifespan of iguanas in the sample.

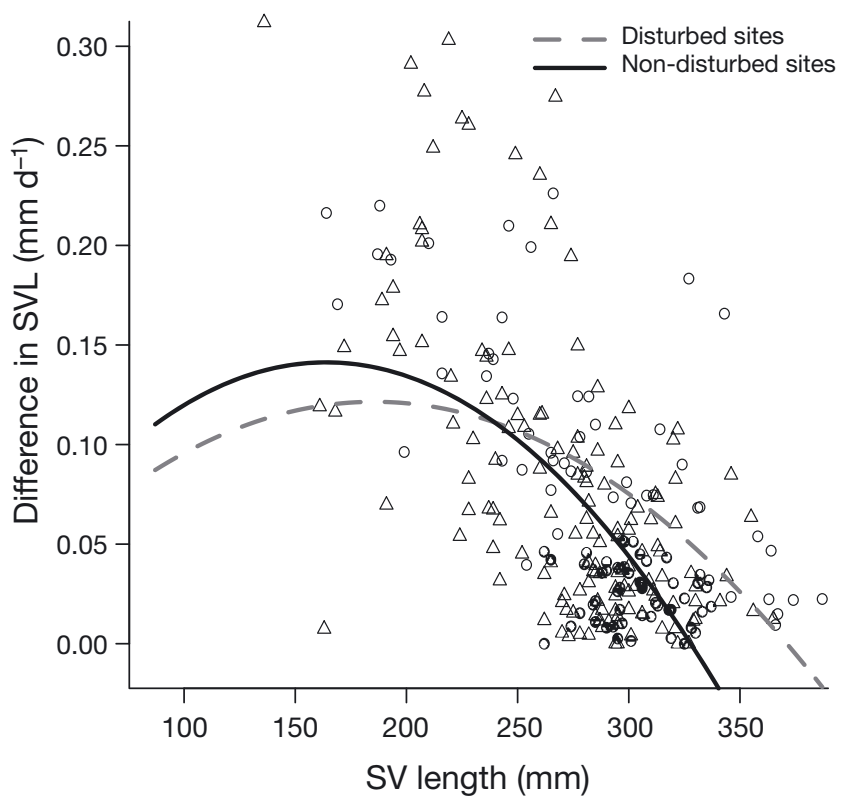

Fig. 1. Iguana delicatissima. Plot of absolute growth rates of iguanas by size at initial capture. Curves represent the relationship between growth and initial size for populations from disturbed (dashed line) and non-disturbed (solid line) habitat types, as parameterized by the corresponding logistic-by-length models. Point types indicate individual data points for iguanas from disturbed $(\Delta)$ and non-disturbed $(O)$ sites. SVL: snout-vent length 

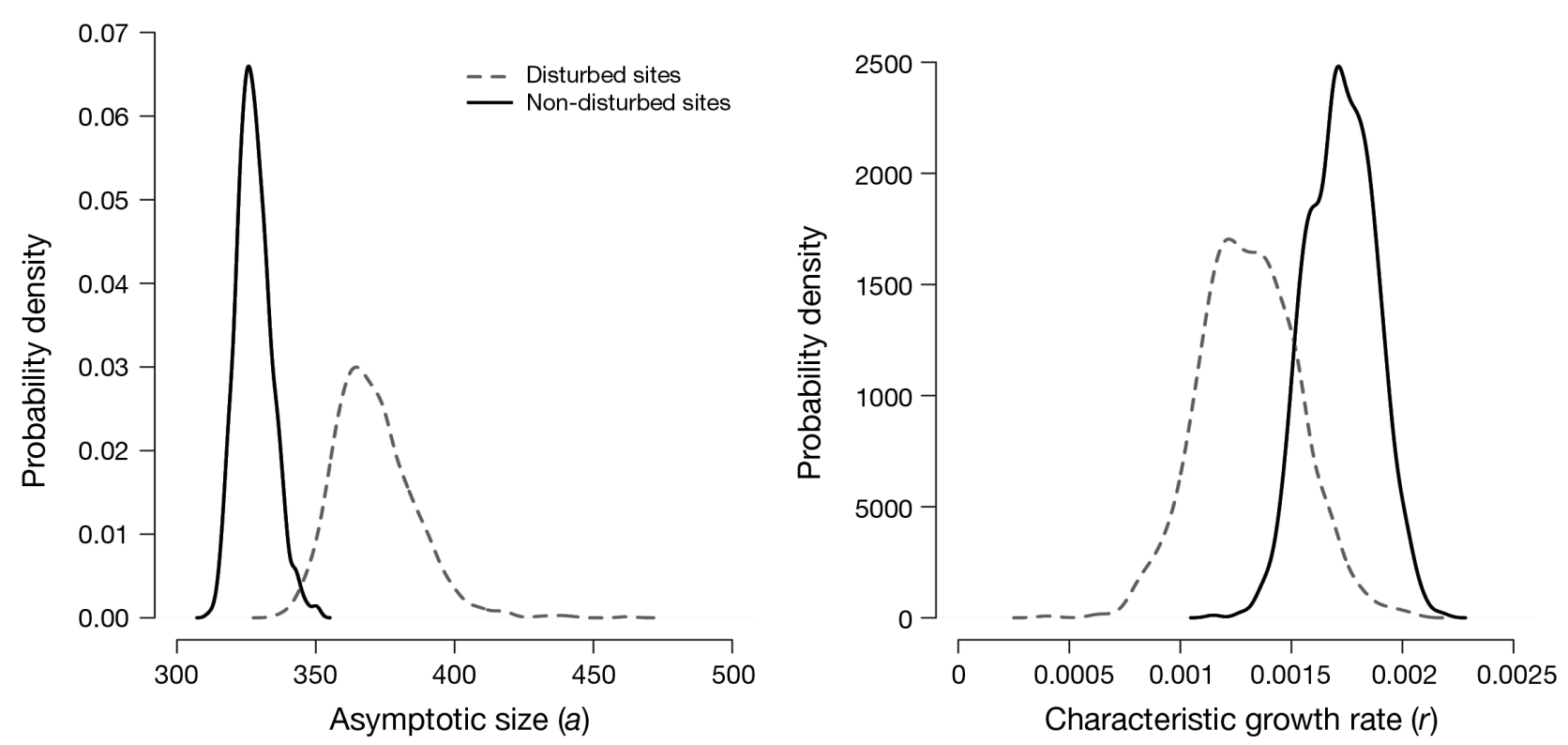

Fig. 2. Distribution of parameter estimates associated with asymptotic size in $\mathrm{mm}(\mathrm{a})$ and characteristic growth rates $(r)$ of Iguana delicatissima. Plots depict the posterior probability distributions of growth model parameters estimated through Markov chain Monte Carlo methods under a Bayesian framework. Estimates of characteristic growth rates did not differ significantly between disturbed and non-disturbed sites, as the posterior distributions of respective $r$ estimates overlapped completely. However, estimates of asymptotic size (a) differed significantly between disturbed and non-disturbed sites

Asymptotic size (a), was different between area types, with higher estimates associated with disturbed areas $\left(a_{\text {disturbed }}=371.1 \mathrm{~mm}, 95 \% \mathrm{CI}=\right.$ $347.6-402.4 ; a_{\text {non-disturbed }}=327.9 \mathrm{~mm}, 95 \% \mathrm{CI}=$ 317.2-342.2; Fig. 2). Although $r$ did not vary by site disturbance, growth curves for the 2 area types are slightly different because of the differences in parameter estimates of a (Fig. 1). We found no significant differences between sex ratios at disturbed or nondisturbed sites $\left(\chi_{1}^{2}=0.0265, p=0.87\right.$; Table 1$)$. Body condition of iguanas also did not differ significantly between disturbed $\left(\mu_{\text {disturbed }}=0.0450\right)$ and non-disturbed $\left(\mu_{\text {non-disturbed }}=0.0448\right)$ sites $(t=-0.168, \mathrm{p}=$ 0.86). Abundance was greater at non-disturbed sites but densities were not significantly different between sites (Table 1).

\section{DISCUSSION}

Contrary to expectations, data from this study suggest that there is no statistically detectable effect of disturbed areas on density, sex ratio, body condition, or characteristic growth rates, yet a slight positive effect on asymptotic body size for iguanas inhabiting low-density villages and towns on Dominica. Iguanas typically respond negatively to disturbance (Alberts 2000), yet some can adapt to altered and highly humanized environments (Fitch et al. 1982, González-García et al. 2009). Populations of 2 iguana species, Iguana iguana and Ctenosaura similis, are established and thrive in human-altered habitat in the southern United States and coastal Venezuela, respectively (Townsend et al. 2003, Barrio-Amorós \& Rivas-Fuenmayor 2008). Although these populations occur outside their natural range, both species can also inhabit disturbed sites within their native range, typically in areas with a high number of ornamental trees, such as town squares and garden patios (González-García et al. 2009, C. R. Knapp pers. obs.).

A factor potentially contributing to the success of species in human-altered areas is high food abundance year round (Williams et al. 2006, Rutz 2008). Indeed, the abundance of ornamental, or preferred locally-adapted, vegetation is considered an important biotic factor facilitating the prevalence of iguanas in human-modified areas (González-García et al. 2009, Meshaka et al. 2009). We suspect that Iguana delicatissima inhabiting disturbed areas on Dominica also benefit from plants and trees associated with home gardens. During the dry season, native tree and shrub species in non-disturbed coastal areas drop leaves, resulting in a conspicuous barren landscape with less available food for iguanas. Conversely, iguanas inhabiting coastal 
villages exploit the fruit, flowers, and leaves of ornamental and fruit trees from locally-watered gardens (C. R. Knapp pers. obs.), thus offsetting a potential state of reduced feeding opportunities at dry times of year.

We stress caution when interpreting our data because comprehensive impacts of human-altered areas are complex and influenced by the degree of disturbance. For the purposes of ecological studies, urban centers have been quantified as containing more than 2500 people (Dumouchel 1975). All human-altered habitats in our study, except Portsmouth, were low-density villages of fewer than 2500 people. Unlike high-density urban centers, such as the capital city of Roseau, most low-density villages on Dominica retain central rivers with forested banks and green space, which may provide adequate - and perhaps more stable - food resources for iguanas. Additionally, the temporal scale of this study was restricted to identifying short-term impacts of habitat disturbance. Understanding longterm impacts will require further longitudinal research.

We recognize that Iguana delicatissima is affected adversely by manifold threats, as evidenced by the continued precipitous declines and local extirpations of the species across its range. Though our study was focused primarily at the level of the individual, it is important to distinguish between individualand population-level processes when evaluating habitat quality (Skagen \& Yackel Adams 2011). Throughout our study, hatchling iguanas were observed and captured by noose more frequently at our non-disturbed study areas but rarely at our disturbed study areas $\left(\mathrm{n}_{\text {non-disturbed }}=22 ; \mathrm{n}_{\text {disturbed }}=1\right)$. The skewed adult demography may be the result of hatchling-biased predation by non-native mammalian predators (Gillies \& Clout 2003) or a lack of suitable nesting sites in disturbed areas. We conducted a hatchling study concurrent with this investigation and recorded 1369 emergent hatchlings over a 2 yr period at our non-disturbed Batali Beach site. We were unable, however, to find active iguana nest sites from any disturbed site. Indeed, our conversations with villagers confirmed the killing of adult nesting females by resident dogs on beaches within some communities. In these cases, the risk of extinction is likely to be greater for populations occurring in, or in this case, migrating to disturbed areas. Additional studies are needed to determine whether these areas are serving as sinks because of decreased reproductive success (e.g. Pulliam \& Danielson 1991).
Though iguana densities among our disturbed and non-disturbed sites were similar, abundance was lower at disturbed sites because of the small size of most forested remnants. Lower abundance may affect the persistence of iguana populations given that theories of stochastic extinction predict higher extinction rates for small compared with large populations. Higher rates are often attributed to the increased vulnerability to proximate causes of extinction such as demographic and environmental stochasticity, genetic deterioration, and social dysfunction (e.g. Lande 1993, Pimm et al. 1993, Henle et al. 2004). In addition, individuals residing in disturbed areas are exposed to a different array of stressors relative to their counterparts in non-disturbed areas. These stressors may impose substantial physiological constraints, such that fitness may be significantly affected in the long term, or individuals may be forced to alter their behavior and life history strategies (Ditchkoff et al. 2006, French et al. 2010).

It is clear that a multitude of factors are contributing to the overall decline of Iguana delicatissima (see Breuil et al. 2010). A more comprehensive understanding of behavior, demography, and life history traits of iguana populations inhabiting disturbed areas is necessary to determine why and which demographic stages are most affected. However, it is evident that the loss and degradation of habitat in the Lesser Antilles will continue at least in the short term. Wildlife managers need many tools to reduce population declines until additional studies are conducted and there is political will for bold conservation initiatives. Our results suggest that if factors such as degradation of nest sites and killing by non-native mammalian predators are mitigated, then moderately disturbed, human-occupied areas can be managed as corridors or buffer zones for I. delicatissima living in increasingly fragmented landscapes.

Acknowledgements. We thank the Dominica Forestry, Wildlife and Parks Division (DFWPD) for permission to conduct research on the island. A. James from the DFWPD provided valuable information and support for the program and this manuscript. A. Phillips helped initiate the research. We are especially grateful to L. Prince, who was an invaluable assistant in the field. Other assistants include A. Mitchell, P. Meier, P. Shirk, J. Valasco Reyes, and G. Gerber. A. Alberts, A. James, G. Gerber, and 3 anonymous reviewers provided valuable comments on the manuscript. The Sunset Bay Club provided comfortable logistical support. San Diego Zoo Global supported all aspects of the study through a Conservation Research Postdoctoral Fellowship. This work was approved by the Zoological Society of San Diego Institutional Animal Care and Use Committee. 


\section{LITERATURE CITED}

Alberts AC (ed) (2000) West Indian iguanas: status survey and conservation action plan. International Union for the Conservation of Nature, Gland

Andrews RM (1976) Growth rate in island and mainland anoline lizards. Copeia 1976:477-482

Andrews RM (1982) Patterns of growth in reptiles. In: Gans C, Pough F (eds) Biology of reptilia, Vol 13. Academic Press, New York, NY, p 273-319

Barrio-Amorós CL, Rivas-Fuenmayor G (2008) Spiny-tailed iguanas (Ctenosaura similis) in Venezuela: a preliminary report. Iguana 15:160-161

Bender DJ, Contreras TA, Fahrig L (1998) Habitat loss and population decline: a meta-analysis of the patch size effect. Ecology 79:517-533

Bolger DT, Suarez AV, Crooks KR, Morrison SA, Case TJ (2000) Arthropods in urban habitat fragments in southern California: area, age, and edge effects. Ecol Appl 10: 1230-1248

Bolger DT, Beard KH, Suarez AV, Case TJ (2008) Increased abundance of native and non-native spiders with habitat fragmentation. Divers Distrib 14:655-665

Breuil M, Day M, Knapp C (2010) Iguana delicatissima. In: IUCN 2010. IUCN Red List of Threatened Species, Version 2010.4. www.iucnredlist.org

Case TJ, Bolger DT, Richman AD (1992) Reptilian extinctions: the last ten thousand years. In: Fiedler PL, Jain SK (eds) Conservation biology: the theory and practice of nature preservation and management. Chapman and Hall, New York, NY, p 91-125

Clobert J, Garland T, Barbault R (1998) The evolution of demographic tactics in lizards: a test of some hypotheses concerning life history evolution. J Evol Biol 11:329-364

Debinski DM, Holt RD (2000) A survey and overview of habitat fragmentation experiments. Conserv Biol 14: 342-355

> Ditchkoff SS, Saalfeld ST, Gibson CJ (2006) Animal behavior in urban ecosystems: modifications due to humaninduced stress. Urban Ecosyst 9:5-12

Dominica Central Statistics Office (2001) Dominica population and housing census report. Ministry of Finance and Planning, Government of Dominica, Roseau

Dumouchel JR (1975) Dictionary of development terminology. McGraw-Hill, New York, NY

- Estrada A, Mendoza A, Castellanos L, Pacheco R, Van Belle S, García Y, Muñoz D (2002) Population of the black howler monkey (Alouatta pigra) in a fragmented landscape in Paleneque, Chiapas, Mexico. Am J Primatol 58: 45-55

> Fagan WF, Aumann C, Kennedy CM, Unmack PJ (2005) Rarity, fragmentation, and the scale dependence of extinction risk in desert fishes. Ecology 86:34-41

Fahrig L (2003) Effects of habitat fragmentation on biodiversity. Annu Rev Ecol Syst 34:487-515

Fitch HS, Henderson RW, Hillis DM (1982) Exploitation of iguanas in Central America. In: Burghardt GM, Rand AS (eds) Iguanas of the world: their behavior ecology and conservation. Noyes Publications, Park Ridge, NJ, p 397-417

- Fitze PS, Le Galliard J (2008) Operational sex ratio, sexual conflict and the intensity of sexual selection. Ecol Lett 11: 432-439

French SS, DeNardo DF, Greives TJ and others (2010) Human disturbance alters endocrine and immune responses in the Galapagos marine iguana (Amblyrhynchus cristatus). Horm Behav 58:792-799

Gillies C, Clout M (2003) The prey of domestic cats (Felis catus) in two suburbs of Auckland City. NZ J Zool 259: 309-315

González-García A, Belliure J, Gómez-Sal A, Dávila P (2009) The role of urban greenspaces in fauna conservation: the case of the iguana Ctenosaura similis in the 'patios' of León city, Nicaragua. Biodivers Conserv 18:1909-1920

> Henle K, Sarre S, Wiegand K (2004) The role of density regulation in extinction processes and population viability analysis. Biodivers Conserv 13:9-52

> Honegger RE (1981) List of amphibians and reptiles either known or thought to have become extinct since 1600 . Biol Conserv 19:141-158

Jenssen TA, Decourcy KR, Congdon JD (2005) Assessment in contests of male lizards (Anolis carolinensis): How should smaller males respond when size matters? Anim Behav 69:1325-1336

> Kiefer MC, Van Sluys M, Rocha CFD (2008) Clutch size and egg size of the tropical lizard Tropidurus torquatus (Tropiduridae) along its geographic range in coastal eastern Brazil. Can J Zool 86:1376-1388

Knapp CR, Iverson JB, Owens AK (2006) Geographic variation in nesting behavior and reproductive biology of an insular iguana (Cyclura cychlura). Can J Zool 84: 1566-1575

> Lande R (1993) Risks of population extinction from demographic and environmental stochasticity and random catastrophe. Am Nat 142:911-927

Lunn DJ, Thomas A, Best N, Spiegelhalter D (2000) WinBUGS - a Bayesian modelling framework: concepts, structure, and extensibility. Stat Comput 10:325-337

Malhotra A, Thorpe RS, Hypolite E, James A (2007) A report on the status of the herpetofauna of the Commonwealth of Dominica, West Indies. Appl Herpetol 4: 177-194

Meshaka WE, Smith HT, Cress HL, Sekscienski SR, Mapp WR, Cowan EM, Moore JA (2009) Raccoon (Proycon lotor) removal and the rapid colonization of the green iguana (Iguana iguana) on a public land in South Florida: a conservation opportunity for the Caribbean. Caribb J Sci 45:15-19

Milberg P, Tyrberg T (1993) Naive birds and noble savages - a review of man-caused prehistoric extinctions of island birds. Ecography 16:229-250

Pafilis P, Meiri S, Foufopoulos J, Valakos E (2009) Intraspecific competition and high food availability are associated with insular gigantism in a lizard. Naturwissenschaften 96:1107-1113

Pike DA, Croak BM, Webb JK and others (2010) Subtle - but easily reversible - anthropogenic disturbance seriously degrades habitat quality for rock-dwelling reptiles. Anim Conserv 13:411-418

> Pimm SL, Diamond J, Reed TM, Russell GJ, Verner J (1993) Times to extinction for small populations of large birds. Proc Natl Acad Sci USA 90:10871-10875

> Pregill GK, Steadman DW (2009) The prehistory and biogeography of terrestrial vertebrates on Guam, Mariana Islands. Divers Distrib 15:983-996

> Pulliam HR, Danielson BJ (1991) Sources, sinks, and habitat selection - a landscape perspective on population dynamics. Am Nat 137:S50-S66

Rutz C (2008) The establishment of an urban bird population. J Anim Ecol 77:1008-1019 
Schoener TW, Schoener A (1978) Estimating and interpreting body-size growth in some anolis lizards. Copeia 1978:390-405

Skagen SK, Yackel Adams AA (2011) Potential misuse of avian density as a conservation metric. Conserv Biol 25: 48-55

Stevenson RD, Woods WA Jr (2006) Condition indices for conservation: new uses for evolving tools. Integr Comp Biol 46:1169-1190

Sturtz S, Ligges U, Gelman A (2005) R2WinBUGS: a package for running WinBUGS from R. J Stat Softw 12:1-16

Suhonen J, Hilli-Lukkarinen M, Korkeamäki E, Kuitunen M, Kullas J, Penttinen J, Salmela J (2010) Local extinction of dragonfly and damselfly populations in low- and high-quality habitat patches. Conserv Biol 24: 1148-1153

Townsend JH, Krysko KL, Enge KM (2003) Introduced iguanas in southern Florida: a history of more than 35 years. Iguana 10:111-118

Van Devender RW (1982) Growth and ecology of spinytailed and green iguanas in Costa Rica, with comments on the evolution of herbivory and large body size. In:
Burghardt GM, Rand AS (eds) Iguanas of the world: their behavior, ecology, and conservation. Noyes Publications, Park Ridge, NJ, p 162-183

Wang Y, Zhang J, Feeley KJ, Jiang P, Ding P (2009) Life-history traits associated with fragmentation vulnerability of lizards in the Thousand Island Lake, China. Anim Conserv 12:329-337

Webb JK, Christian KA, Fisher P (2002) Fast growth and early maturation in a viviparous sit-and-wait predator, the northern death adder (Acanthophis praelongus), from tropical Australia. J Herpetol 36:505-509

White GC, Burnham KP (1999) Program MARK: survival estimation from populations of marked animals. Bird Study 46(Suppl):120-138

> Williams NSG, McDonnell MJ, Phelan GK, Keim LD, Van der Ree R (2006) Range expansion due to urbanization: increased food resources attract grey-headed flyingfoxes (Pteropus poliocephalus) to Melbourne. Austral Ecol 31:190-198

> Wilson BS, Horrocks JA, Hailey A (2006) Conservation of insular herpetofaunas in the West Indies. Appl Herpetol 3:181-195

Appendix 1. WinBUGS code for the logistic-by-length model defined by Schoener \& Schoener (1978)

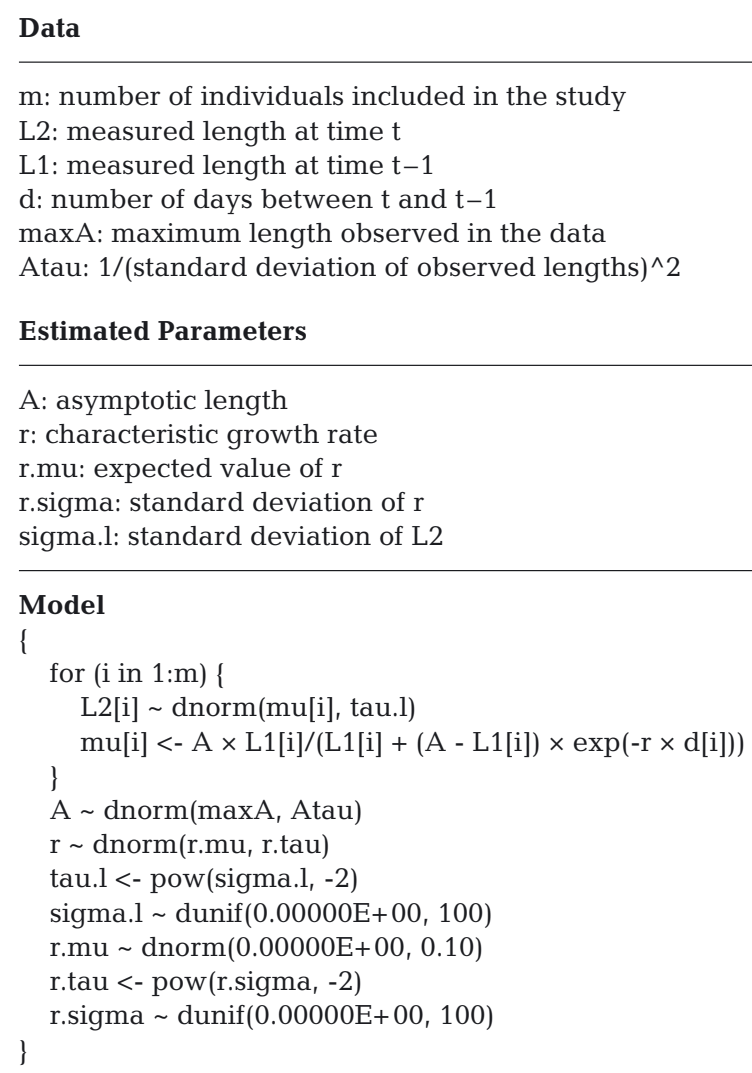

